\title{
Resource selection by tuatara following translocation: a comparison of wild-caught and captive-reared juveniles
}

\author{
Scott Jarvie $^{1 *}$, Mariano R. Recio ${ }^{1,2}$, Stephen C. Adolph ${ }^{1,3}$, Philip J. Seddon ${ }^{1}$ and Alison Cree ${ }^{1}$ \\ ${ }^{1}$ Department of Zoology, University of Otago, PO Box 56, Dunedin 9054, New Zealand \\ ${ }^{2}$ School of Surveying, University of Otago, PO Box 56, Dunedin 9054, New Zealand \\ ${ }^{3}$ Department of Biology, Harvey Mudd College, 301 Platt Boulevard, Claremont, California 91711, USA \\ *Author for correspondence: (Email: sjarvie@gmail.com)
}

Published online: 11 March 2016

\begin{abstract}
Animal reintroduction is an important tool for species conservation, but success rates can be low. Comparative studies can be used to identify factors that influence success during translocations. We studied the reintroduction of captive-reared and wild-caught juveniles of an iconic reptile, the tuatara Sphenodon punctatus, on the South Island of New Zealand. We followed juveniles from three treatment groups (wild-caught and from two outdoor head-start facilities, all of the same genetic stock) during the initial five months of the establishment phase. We compared resource selection at three scales: landscape, high-use areas, and retreat-sites. At the landscape scale, juvenile tuatara from all groups remained in forest habitats similar to those where they were released, which also had the highest night-time operative temperatures (theoretically equilibrated body temperatures); in high-use areas they chose to be close to cover; and for retreat-sites they selected burrows. Our results demonstrate that juvenile tuatara, irrespective of group, used similar resources, and suggest that either wild-caught or captive-reared juveniles could be used as founders for future translocations.
\end{abstract}

Keywords: compositional analysis; head-starting; reintroduction; reptile; resource selection function; Rhynchocephalia; selectivity index; Sphenodon punctatus

\section{Introduction}

Reintroduction, the intentional release of organisms within part of their indigenous range from which they have disappeared, is increasingly used in species conservation (Seddon et al. 2007; IUCN/SSC 2013). Reintroduction programmes often require the use of captive-reared animals for release, but comparative studies suggest that post-release performance and survival are generally lower for captive-reared animals than for wild-towild translocated individuals (Griffith et al. 1989; Wolf et al. 1996; Fischer \& Lindenmayer 2000). Such observations have led to increased interest in factors that influence the success of conservation translocations (Armstrong \& Seddon 2008; Seddon et al. 2014; Kemp et al. 2015).

Resource selection can have a profound influence on the success of animal reintroductions (Stamps \& Swaisgood 2007; Osborne \& Seddon 2012). Behavioural deficiencies of captive-reared animals from time spent in captivity, including inappropriate resource selection (Roe etal.2010), are a common problem in translocations (Snyder et al. 1996). Alternatively, wild-to-wild translocated animals often reject what might be perceived by them to be unsuitable resources at the release site and rapidly disperse over long distances (Kokko \& Sutherland 2001; Stamps \& Swaisgood 2007). Thus, both captive-reared and wild-caught animals might rely on misleading cues when they encounter unfamiliar environments (Davis \& Stamps 2004; Stamps \& Swaisgood 2007). Comparative studies can be used to test the utility of common translocation strategies (Armstrong \& Seddon 2008), and can lead to a better understanding of the outcome of a particular manipulation (Sarrazin \& Barbault 1996; Armstrong \& Seddon 2008). Thus, comparative studies provide best possible evidence to inform future translocations (Seddon et al. 2007; Kemp et al. 2015).
In this study we compared resource selection by wild-caught and captive-reared juvenile tuatara Sphenodon punctatus during the initial establishment phase of a reintroduction (sensu IUCN/SSC 2013).

Tuatara are the sole extant representative of Rhynchocephalia, the sister group to Squamata (lizards and snakes) (Jones \& Cree 2012). Once widely distributed throughout New Zealand, tuatara now naturally inhabit only 32 offshore islands (Gaze 2001). Tuatara disappeared from the New Zealand mainland (North and South Islands) (Cree 2014) following the arrival of humans and mammalian predators $\sim 730 \mathrm{BP}$ (Wilmshurst et al. 2008). Translocations are an important part of the recovery goal for tuatara, providing insurance populations to help safeguard the species' long-term persistence (Miller et al. 2012; Jarvie et al. 2014a). Recent advances in techniques for eradication of introduced mammals and in fencing to prevent mammals from reinvading (Burns et al. 2012) have increased the potential number of release areas for tuatara on the New Zealand mainland (Miller et al. 2012).

Translocations of tuatara have already taken place (e.g., Nelson et al. 2002), although no studies, to date, have assessed resource selection by translocated tuatara. Translocated populations have been founded by wild-caught individuals and/or by juveniles that were raised in captivity before release - a strategy known as head starting. Head starting works on the assumption that young animals get reared in captivity until they reach a larger, presumably less vulnerable body size, before release into the wild (Pritchard 1979). Here we compared resource selection by head-started and wild-caught juvenile tuatara reintroduced to Ōrokonui Ecosanctuary (Te Korowaio Mihiwaka; $45^{\circ} 46^{\prime} \mathrm{S}, 170^{\circ} 36^{\prime} \mathrm{E}$; hereafter Ōrokonui), a mainland reserve in the southeastern South Island of New Zealand. This research complements a study that compared 
behavioural, ecophysiological, and spatial (home range size and dispersal distance) characteristics, and ultimately survival, of the wild-caught and head-started juveniles, which were all genetically of Stephens Island/Takapourewa origin (Jarvie et al. 2015). Although Jarvie et al. (2015) found that post-release performance of wild-caught and head-started tuatara was similar for most of the metrics compared, there were differences among groups in inferred body temperature, emergence patterns and growth rates during the initial establishment phase of the reintroduction.

Given that resource selection is a spatially hierarchical process (Johnson 1980), the ecological context of wildlifehabitat relationships can be characterised using multi-scale modelling (Manly et al. 2002). We therefore compared resource selection by juvenile tuatara at three scales: landscape-scale use within the study site; local-scale selection within the largest recorded movement of tuatara between monitoring trips; and the selection of retreat sites over a 5-month period following release. The period following release is critical for the long-term success of a translocation (Seddon et al. 2007) because a population can fail to survive in an environment that could allow persistence once established (Armstrong \& Seddon 2008; Kemp et al. 2015). We predicted that wild-caught juveniles would select warmer areas of habitat than head-started individuals, and that this would explain the faster growth rates observed for wild-caught individuals compared with their head-started conspecifics during the initial establishment phase of the reintroduction (Jarvie et al. 2015).

\section{Materials and methods}

\section{Study species}

Tuatara are a medium-sized (juvenile snout-vent length $<170$ $\mathrm{mm}$ ), diurno-nocturnal, burrowing reptile (Jones \& Cree 2012). They are long-lived and late maturing ( $>13$ years), with low reproductive output (Cree 1994). Tuatara rely on crypsis to avoid native avian predators and have secretive behaviours (Cree 2014), particularly for hatchlings and small juveniles (Dawbin 1982), making detection probabilities low. On Stephens Island, which has the largest population of tuatara estimated at 30-50,000 individuals (Newman 1987), tuatara density is highest in forest remnants (probably the preferred habitat, as evidenced by much higher densities in the forest than in open-rank grass areas; e.g. Moore et al. 2007).

\section{Reintroduced juvenile tuatara and release site}

Juvenile tuatara reintroduced to Ōrokonui came from three groups: 1) wild-caught juveniles transferred directly from Stephens Island $\left(40^{\circ} 35^{\prime} \mathrm{S}, 173^{\circ} 55^{\prime} \mathrm{E}\right)$; 2) head-started juveniles from Nga Manu Nature Reserve $\left(40^{\circ} 87^{\prime} \mathrm{S}, 175^{\circ} 06^{\prime} \mathrm{E}\right)$ in Waikanae, $480 \mathrm{~km}$ north of Ōrokonui, thus a warmer location (hereafter HS-warmer); 3) head-started juveniles from Ōrokonui, thus adjusted to the local climate (hereafter HS-local). Captive-reared juveniles were head-started for 4-6 years in semi-natural outdoor enclosures that encouraged normal behaviour. They were able to dig their own burrows and search for food (extra food was also provided), and flying predators were visible through the roof. All juveniles were reintroduced to Ōrokonui in the austral summer (OctoberDecember 2012; see Jarvie et al. 2014a,b, 2015), a period of increasing temperatures and activity for tuatara (Cree 2014). We installed artificial burrows $\left(\sim 500 \times 65 \mathrm{~mm}\right.$; Novaflo ${ }^{\mathrm{TM}}$,
London, UK) at a density of less than one per $5 \mathrm{~m}^{2}$ in a $\sim 250$ $\mathrm{m}^{2}$ area of forest (most in regenerating native forest with kānuka (Kunzea ericoides) canopy; hereafter "kānuka forest") to provide shelter for juveniles upon release. All radio-tagged juvenile tuatara used in this resource-selection study (see below for details of transmitter attachment) were released into burrows in kānuka forest in this $250-\mathrm{m}^{2}$ area, at a similar density to that of adult tuatara on Stephens Island (Newman 1987). Weather conditions remained stable throughout the study period (Jarvie et al. 2015) and animals were released into otherwise tuatara-free habitat (Jarvie et al. 2014b, 2015).

The release site, Ōrokonui, is a 307-hectare mainland reserve enclosed by a predator-resistant fence (Burns et al. 2012). In 2008, introduced mammalian predators were eradicated from the reserve (except for house mice Mus musculus, which remain near the threshold of detectability), enabling translocation programmes that contribute to the restoration of the sanctuary's ecosystem. The vegetation near the release area is mostly regenerating native kānuka forest, with small remnants of mixed forest (Coprosma spp., Melicytus ramiflorus, Myrsine australis, Pittosporum eugenioides), modified bush-margins of bracken (Pteridium exculentrum), and open habitat with exotic grasses. Kānuka and mixed forest have a diverse understory of shrubs (Coprosma spp., Carpodetus serratus, M. australis, $P$. eugenioides, Pseudowintera colorata, Aristotelia serrata), ferns (Asplenium bulbiferum, Blechnum procerum, Hypolepis ambigua, Polystichum vestitum, Microsorum pustulatum), bush lily (Astelia fragrans) and bracken. Örokonui is outside the current distribution of tuatara, but within the indigenous range of the genus (Crook 1975; Cree 2014). This reintroduction is the first time that tuatara have been essentially free-ranging on the southern South Island in the past few hundred years (Jarvie et al. 2014a).

\section{Post-release monitoring}

We attached transmitters (PD-2T, Holohil Systems Ltd., Ontario, Canada) to 26 juvenile tuatara: 10 wild-caught, 10 head-started at HS-warmer, and 6 head-started at HS-local. All transmitters and harnesses weighed less than $5.4 \%$ of the animals' body weights (see Jarvie et al. 2014b for details of transmitter attachment). The 26 radio-tagged individuals were a subset of the 57 translocated juveniles released ( 30 wild-caught adults were also released nearby during the austral summer) (see Jarvie et al. 2015 for details). We used radio-telemetry to locate juveniles twice-weekly (once during the day, once at night; Jarvie et al. 2014b). Individual tuatara tracking times varied throughout the day-night cycle to avoid patterns caused by timing of sightings. Radio-tagged animals did not differ behaviourally from non-radio-tagged individuals (Jarvie et al. 2014b). We obtained approximately 40 locations per animal over the course of the study (Jarvie et al. 2015).

\section{Resource selection analyses}

We carried out resource selection analyses to compare wildcaught and head-started juvenile tuatara at three scales: landscape, local, and retreat site. All resource selection analyses were performed in R v 3.0.1 (R Development Core Team 2015).

\section{Landscape scale}

To compare resource selection at the landscape scale we followed a used vs available design, which compares the characteristics of the surrounding environment where an 
individual is located, with resource availability at random positions selected within the study area (Boyce et al. 2002). We estimated availability by sampling three random points per used location, selected for each individual within the maximum distance dispersed from the release site by any juvenile (108.6 $\mathrm{m})$. Available locations were randomly selected using GIS software (resolution of base map $5 \mathrm{~m}$; ArcGIS v10.1; ESRI, California, USA) and ground-truthed with a hand-held GPS unit (accurate to $\pm 4 \mathrm{~m}$; GPSMAP ${ }^{\circledR} 60 \mathrm{CSx}$, Garmin Internal, Kansas, USA). We quantified habitats on-site in each used (animal) and available (random) location. Habitat types were categorised primarily on canopy cover, but also with reference to canopy height and substrate type (e.g. Hoare et al. 2007). The four habitat types at the landscape scale were: kānuka (forest), mixed (forest), bracken, and open-rank grass. All four habitat types were available within $25 \mathrm{~m}$ of any release burrow. We used compositional analysis to describe the composition and ranking of use at the landscape scale (Aebischer et al. 1993). Compositional analysis compares the relative proportions of resource used by the individual to the habitat's relative availability on the site, and is carried out in two steps: 1) Wilks's lambda is used to test the significance of resource selection; and 2) the resources are ranked indicating which resources are used significantly more or less (Aebischer et al. 1993). We acknowledge that because radio-tagged juveniles were released in burrows in one habitat type (kānuka), our inferences about landscape selection are limited (see Discussion). To avoid invalid log-ratio transformations we replaced zero values of habitat use by a small constant (0.01), following Aebischer et al. (1993). Compositional analysis was conducted separately for each group using the compana function in the $\mathrm{R}$ package adehabitatHS (Calenge 2006).

We deployed operative temperature models (Bakken \& Gates 1975) to infer whether temperature differences might influence habitat use by juvenile tuatara at the landscape scale. Operative temperature models, which measured the thermal characteristics of the four habitats at night when tuatara roam most widely (Cree 2014), estimate the steadystate temperature that would be achieved by an organism in a specific microhabitat (Bakken \& Gates 1975; Bakken \& Angilletta 2013). We used operative temperature models that had previously been calibrated against live juvenile tuatara (Besson \& Cree 2010), and deployed 10 models in each of kānuka, mixed, and bracken, and five in open-rank grass habitats from 15 December 2012 to April 72013 (the end of the study period). Operative temperature models were placed in potential locations for emerged tuatara, ranging from fully shaded sites to relatively exposed sites. Temperatures within the physical models were measured once per hour using iButton data loggers with a resolution of $0.5^{\circ} \mathrm{C}$ (DS 1922, Maxim Integrated Products, CA, USA). We estimated pairwise differences in the operative temperatures between habitats using linear mixed effect models (LMM) in the R package nlme with the lme function (Venables \& Ripley 2002; Pinheiro et al. 2014), where the response variable was temperature, the fixed-factor was habitat (a four-level categorical variable) and the random-factor was the physical model ID.

\section{Local scale}

We compared resource selection at the local scale using resource selection functions for each group, with a used vs available design similar to that used at the landscape scale. Resource selection functions were used to compare resource covariates at used locations with two random (available) locations, chosen at a distance less than the largest recorded movement (between the twice-weekly monitoring trips) from juveniles during the first 3 months of the reintroduction (i.e. < $24 \mathrm{~m}$ ). We assumed this selection of random locations operates at a scale realistic to the selection decisions made by juvenile tuatara. The landscape covariates measured at used and random locations were: distance to a cover object (DCO), defined as the nearest vegetation or retreat that can act a potential refuge for a reptile, as described by Martin and Lopez (1995); and the percentage canopy cover above where the juvenile was found (e.g. in burrow, under vegetation or emerged) at $30 \mathrm{~mm}$ (CC30) and at $1200 \mathrm{~mm}(\mathrm{CC} 1200)$, measured vertically. Canopy cover was measured at both heights because the amount of canopy cover can influence body temperature and/or predation risk for reptiles (Lima \& Dill 1990). We measured distance to cover object (to the nearest $10 \mathrm{~mm}$ ) using a tape measure, and percentage of canopy cover with a spherical densitometer (following the manufacturer's instructions; Forestry Suppliers Inc., Jackson, MS, USA).

We estimated resource selection functions using generalised linear mixed models with binomial error structure and logit link function, where the binomial response variable was coded 1 for used locations and 0 for available locations, and the random factor was an individual identifier to take into account the unbalanced sampling design (Gillies et al. 2006). For each group, we generated models with all possible combinations of the three predictors DCO, CC 30 and CC1200 (see above), as none were highly correlated $(|r|>0.7$, cut-off value following Dormann et al. (2013)). We standardised all predictor variables in models to a mean of 0 and a SD of 0.5 to facilitate interpretation following Schielzeth (2010). All models were ranked on the basis of model-averaging using small-sample-size-corrected Akaike's Information Criterion $\left(\mathrm{AIC}_{\mathrm{c}}\right.$; Burnham \& Anderson 2002). We model-averaged parameters from models within $6 \mathrm{AIC}_{\mathrm{c}}$ units (i.e. $\Delta \mathrm{AIC}_{\mathrm{c}} \leq 6$ ) of the best model (that with the lowest $\mathrm{AIC}_{\mathrm{c}}$; Symonds \& Moussalli 2011), using the natural-average method (Burnham \& Anderson 2002; Nakagawa \& Freckleton 2010). This analysis has two outputs: standardised parameter estimates (and their unconditional standard errors, which incorporate model-selection uncertainty); and relative importance of each parameter for explaining the variance in the response variable. Before model-averaging, we checked that at least one model containing each of the predictor variables was within $6 \mathrm{AIC}_{\mathrm{c}}$ of the best model for each group. This allowed for effects of each predictor variable to be estimated. Resource selection functions were conducted in R following Grueber et al. (2011), using the glmer function in the lme 4 package (Bates et al. 2015), the scale function in the base package ( $\mathrm{R}$ Development Core Team 2015), and the dredge and model.avg functions in the MuMIn package (Bartoń 2015).

To evaluate the variance explained we calculated $R^{2}$ values of the global resource selection model for each group, i.e. the model containing all the parameters of interest, using the methods of Nakagawa and Schielzeth (2013) and the r.squaredGLMM function in the MuMIn package (Bartoń 2013). We calculated $R_{\text {GLMM(m) }}^{2}$, the marginal $R^{2}$ that describes the variance explained by the fixed factors, and $R^{2}$ GLMM(c), and the conditional $R^{2}$ that is concerned with the variance explained by both the fixed and random factors (Nakagawa \& Schielzeth 2013). 


\section{Retreat-site selection}

We compared retreat-site selection, with a used vs available design, comparing four retreat cover types for juvenile tuatara: burrow (artificial and natural), wood, bracken, and rank grass. For each used retreat (i.e. where we found a juvenile tuatara) we located two available retreat cover types within $24 \mathrm{~m}$, which could act as a potential refuge for a reptile (Martin \& Lopez 1995). To determine the preference for retreat cover types in each group, we used Manly's Selectivity Index (selection ratio; Manly et al. 2002). The selection ratio $\left(\mathrm{W}_{\mathrm{i}}\right)$ for a given resource category is the ratio of its proportional use to its proportional availability (Manly et al.2002). A ratio close to one indicates no selectivity, $<1$ indicates avoidance, and $>1$ indicates selection for that resource (Alldredge \& Griswold 2006). We calculated Manly's Selectivity Index using the widesIII function in the R package adehabitatHS (Calenge 2006).

\section{Results}

\section{Landscape scale}

During the 5-month study period juvenile tuatara were found in kānuka forest $58.8 \%$ of the time, open-rank grass $20.2 \%$ of the time, bracken $11.1 \%$ of the time, and mixed forest $9.9 \%$ of the time. Compositional analysis revealed that juvenile tuatara from all groups used habitats non-randomly (wildcaught: Wilks's $\lambda=0.12, P<0.01$; HS-warmer: $\lambda=0.04, P$ $<0.01$; HS-local $\lambda=0.02, P<0.05$ ). The ranking of habitat classes for all groups from most to least used was: kānuka $>$ open-rank grass $>$ bracken $>$ mixed.

Mean night-time operative temperatures in the four habitats were ranked in the same order as the compositional analyses for the three groups of juvenile tuatara, with kānuka the warmest habitat $\left(11.8^{\circ} \mathrm{C}\right)$, followed by open-rank grass $\left(11.5^{\circ} \mathrm{C}\right)$, bracken $\left(11.2^{\circ} \mathrm{C}\right)$ and mixed forest as the coldest habitat $\left(11.1^{\circ} \mathrm{C}\right.$ ) (for model coefficients and SEs see Table S1 in online Supplementary Material). Only comparisons between kānuka and bracken and between kānuka and mixed forest were statistically significant (Table S1).

\section{Local scale}

For each group, the global resource selection model explained $86-91 \%\left(R_{\mathrm{GLMM}(\mathrm{c})}^{2}\right)$ of the variation in the data, of which fixed factors and their interactions explained most variation $\left(R_{\mathrm{GLMM}(\mathrm{m})}^{2}\right.$ : wild-caught 0.91 , HS-warmer 0.86 , HS-local $0.87)$. Resource selection functions indicated that for highuse areas the relative importance of variables for wild-caught and head-started juveniles was similar (Table 1; for model coefficients and model rankings see Tables S2, S3 and S4 in online Supporting Material). The variable that explained the most variance for all groups was distance from cover object (Table 1). For all groups, the parameter estimate for distance to cover was negative, indicating that juveniles selected to be close to cover (Table 1).

Despite uncertainty in estimates of canopy cover effects at two heights (unconditional standard errors were high relative to the effects), the relative importance of these predictor variables was generally high (Table 1). For all groups, the parameter estimate for canopy cover at $30 \mathrm{~mm}$ was negative, suggesting juveniles tended to be close to cover (Table 1). In contrast, wild-caught and HS-local juveniles selected canopy cover at $1200 \mathrm{~mm}$ (negative parameter estimates), while HS-warmer individuals avoided canopy cover (positive parameter estimate; Table 1). Two-way interactions of predictors had comparatively minor effects, with high uncertainty (large unconditional standard errors) and parameter estimates varying in direction between groups (Table 1).

\section{Retreat-site selection}

The proportion of juvenile tuatara in retreats during any given tracking period ranged from $56.7 \%$ to $100 \%$, and tuatara were located in refugia $91.7 \%$ of the time. For all groups, Manly's Selectivity Index showed that juvenile tuatara strongly selected for burrows and selected for wood reasonably strongly, but selected against bracken and rank grass (Table 2).

Table 1. Model-averaged standardised predictors of resource selection functions for three groups of juvenile tuatara (Sphenodon punctatus) at the local scale following a reintroduction to Ōrokonui Ecosanctuary, South Island, New Zealand. Wild-caught $=$ transferred directly from Stephens Island/Takapourewa; HS-warmer = head started at Nga Manu Nature Reserve, which is substantially north of Ōrokonui and thus warmer; HS-local = head started at Ōrokonui Ecosanctuary. $\beta$ $=$ standardised parameter estimate; USE = unconditional standard error; RI = relative importance of each parameter to the other parameters in the final model. Results shown are model predictors derived by model-averaging models within 6 AIC $\mathrm{c}_{\mathrm{c}}$ units of the best model (see Methods); model sets used to generate these averages are provided in Table S3. For each group, models included a random factor for individual identity. All predictor variables in models were standardised to a mean of 0 (SD 0.5). Abbreviations for predictor variables are DCO = Distance from cover object; CC $30=$ Canopy cover at $30 \mathrm{~mm}$; $\mathrm{CC} 1200=$ Canopy cover at $1200 \mathrm{~mm}$.

\begin{tabular}{|c|c|c|c|c|c|c|}
\hline \multirow{2}{*}{ Predictor } & \multicolumn{2}{|l|}{ Wild-caught } & \multicolumn{2}{|l|}{ HS-warmer } & \multicolumn{2}{|l|}{ HS-local } \\
\hline & ß (USE) & $\mathrm{RI}$ & $ß$ (USE) & RI & $\beta$ (USE) & RI \\
\hline Intercept & $-3.08(0.39)$ & & $-2.56(0.30)$ & & $-3.14(0.71)$ & \\
\hline $\mathrm{DCO}$ & $-11.33(1.62)$ & 1 & $-6.32(1.74)$ & 1 & $-11.77(3.27)$ & 1 \\
\hline CC1200 & $-0.88(0.82)$ & 1 & $0.53(0.61)$ & 0.77 & $-2.73(1.68)$ & 0.88 \\
\hline $\mathrm{CC} 30$ & $-0.60(0.92)$ & 0.63 & $-3.78(1.34)$ & 1 & $-1.48(2.18)$ & 0.81 \\
\hline $\mathrm{DCO} * \mathrm{CC} 1200$ & $-2.06(4.96)$ & 0.30 & $2.57(2.14)$ & 0.32 & $-10.32(5.34)$ & 0.38 \\
\hline $\mathrm{DCO} * \mathrm{CC} 30$ & $3.14(3.40)$ & 0.21 & $0.25(4.18)$ & 0.27 & $-9.65(9.81)$ & 0.32 \\
\hline $\mathrm{CC} 1200 * \mathrm{CC} 30$ & $0.16(1.46)$ & 0.17 & $0.66(7.72)$ & 0.22 & $-6.41(11.99)$ & 0.66 \\
\hline
\end{tabular}


Table 2. Manly's Selectivity Index for retreat-site selection for juvenile tuatara (Sphenodon punctatus) from three groups following a reintroduction to Ōrokonui Ecosanctuary, South Island, New Zealand. Ratios close to one indicate no selectivity, less than one avoidance and greater than one selection for that resource. $\mathrm{W}_{\mathrm{i}}=$ selection ratio; $\mathrm{SE}=$ standard error. Refer to Table 1 for explanation of group names.

\begin{tabular}{|c|c|c|c|c|}
\hline \multirow{2}{*}{ Group } & Burrow & Wood & Bracken & Rank grass \\
\hline & $\mathrm{W}_{\mathrm{i}}(\mathrm{SE})$ & $\mathrm{W}_{\mathrm{i}}(\mathrm{SE})$ & $\mathrm{W}_{\mathrm{i}}(\mathrm{SE})$ & $\mathrm{W}_{\mathrm{i}}(\mathrm{SE})$ \\
\hline Wild-caught & $150(141.49)$ & $5.42(0.65)$ & $0.48(0.15)$ & $0.16(0.80)$ \\
\hline HS-warmer & 85 (79.90) & $2.87(0.57)$ & $0.73(0.25)$ & $0.23(0.153)$ \\
\hline HS-local & $66(50.60)$ & $3.21(0.47)$ & $0.71(0.68)$ & $0(0)$ \\
\hline
\end{tabular}

\section{Discussion}

Comparative studies testing factors that influence the success of translocation strategies are seldom used in the field of reintroduction biology (Seddon et al. 2007; Armstrong \& Seddon 2008; Kemp et al. 2015). In this study we compared resource selection by two groups of head-started and one group of wild-caught juvenile tuatara that had high survival during the initial establishment phase of a reintroduction (Jarvie et al. 2015). Contrary to our expectations that the resource selection of head-started and wild-caught juveniles would differ, our results suggest that juveniles from all groups used comparable resources at the three spatial scales studied during the initial establishment phase.

\section{Landscape scale}

For many reptiles, resource selection at the landscape scale influences population and community interactions (Huey 1991). Reptiles select resources at the landscape scale based on, for example, predator avoidance (Webb \& Whiting 2005) and thermoregulatory requirements (Blouin-Demers \& Weatherhead 2001a, b). There are three possible but not mutually exclusive reasons for our observation that all groups of juvenile tuatara used similar resources at the landscape scale. First, radio-tagged juvenile tuatara were released into burrows in kānuka forest and, because of their relatively sedentary nature and the deployment of the majority of artificial burrows also in kānuka forest (Jarvie et al. 2014b, 2015; Cree 2014), might not have dispersed into other habitats. Second, forest is presumed to be the preferred habitat of tuatara, as evidenced by the aggressive exclusion of small juveniles (McIntyre, unpublished report 1988) and much higher densities of adult tuatara in forested remnants than other habitats (e.g. McIntyre, unpublished report1988; Moore et al. 2007; Cree 2014). Adult tuatara were absent from the Ōrokonui release area when juveniles were released, and small juveniles might have selected habitat that they would avoid if aggressive adults were present (cf. McIntyre, unpublished report 1988). Third, mean night-time operative temperatures were slightly warmer (by $0.3-0.7^{\circ} \mathrm{C}$ in habitats where most juveniles were found (kānuka forest and open-rank grass) compared with habitats where tuatara were less often found (bracken and mixed)). Tuatara are ectotherms that are most active on warm nights (Walls 1983; Cree 2014), and in principle, warmer operative temperatures in the habitats where juveniles were found might enhance foraging (Greenwald 1974), digestion (Skoczylas 1978) and survivorship (Christian \& Tracy 1981). However, the magnitude of the difference was small and effects of such small differences (if translated into differences in body temperature) on physiological performance in tuatara are uncertain (Besson \& Cree 2010). Nonetheless, by choosing habitats that offer slightly warmer environmental temperatures, tuatara would help compensate for the cooler overall temperatures at the Orokonui release site compared with the temperatures that they experience on Stephens Island (Besson and Cree 2010).

\section{Local scale}

Many reptiles suffer high predation pressure (Martin \& Lopez 1999) and will escape from predators by fleeing into the nearest refuge (Martin \& Lopez 1995). Our finding that reintroduced wild-caught and captive-reared juveniles selected to be near refugia is in agreement with wild populations of tuatara, where hatchling and small juvenile tuatara are inconspicuous and found close to cover objects (e.g. Dawbin 1982; McIntyre, unpublished report 1988). Prehistorically, birds and adult tuatara were the main predators of small juvenile and hatchling tuatara (Cree 2014), and being close to cover might improve the chances for reintroduced juveniles to escape from these native predators (Greene 1988). However, tuatara would be vulnerable to predation from introduced mammals, if present (Cree 2014).

Canopy cover could reduce predation risk for reptiles, and can also influence body temperature (Lima \& Dill 1990). Behavioural thermoregulation for reptiles involves shuttling between microclimates, such as between retreat sites and canopy cover (Huey 1982). The tendency for wild-caught and HS-local juveniles to select a reduced percentage of canopy cover at $1200 \mathrm{~mm}$, compared with HS-warmer individuals, might have allowed them to stay closer to their preferred body temperatures (Besson \& Cree 2010) during the initial establishment phase (Jarvie et al. 2015). Differences in the thermoregulatory behaviour of HS-warmer juveniles, relative to HS-local and wild-caught conspecifics, may be the result of behavioural deficiencies resulting from the time they had spent in a less thermally challenging environment. For example, captive-reared northern water snakes (Nerodia sipedon sipedon) selected inappropriate thermal resources following translocation compared with wild-to-wild translocated and resident conspecifics resulting in poor performance and lower survival rates (Roe et al. 2010). As reptilian growth rate is mainly temperature-dependent (Sinervo \& Adolph 1989; Vitt \& Caldwell 2014), differences in how the similarly selected forest habitat was utilised (via emergence patterns) could in part explain the observed faster growth of wild-caught juvenile tuatara compared with their head-started conspecifics (Jarvie et al. 2015). In addition, wild-caught juveniles may have been more effective foragers than head-started individuals, which were given supplementary food in captivity (DeGregorio et al. 2013; Mello et al. 2013). 


\section{Retreat-site selection}

Many reptiles, including tuatara, shelter within retreat sites for long periods of time (e.g. Huey et al. 1989; Cree 2014). Appropriate retreat sites provide protection from predators (Downes \& Shine 1998), access to prey (Huey \& Pianka 1981), and suitable hydric and thermal conditions (Huey et al. 1989; Huey 1991; Corkery et al. 2014). We found, unsurprisingly, that reintroduced wild-caught and captive-reared juveniles strongly selected burrows as retreat sites. Our results are in agreement with previous studies in which tuatara are commonly described as burrow dwelling (e.g. Mitchell et al. 2010; Cree 2014; Grayson et al. 2014), although, as we observed, they do not exclusively use burrows as retreat-sites. Tuatara are typically philopatric to retreat sites, maintaining relatively simple territorial structure over years (Moore et al. 2009). Since the behavioural and physiological performance of reptiles is related to the microclimates they experience (Huey 1982; Corkery et al. 2014), the environmental conditions within retreat sites can influence fitness (Huey 1991). Future research is needed to monitor philopatry of reintroduced wild-caught and captive-reared juvenile tuatara to retreat sites, and to compare thermal and/or hydric conditions between retreat types.

\section{Conclusion}

Translocations are increasingly used in population restorations (sensu IUCN/SSC 2013; Seddon et al. 2014). Previous studies of translocated reptiles have shown that the origin of individuals influences spatial resource selection (Rittenhouse et al. 2008; Roe et al. 2010), and ultimately fitness (Stamps \& Swaisgood 2007; Roe et al. 2010). In contrast, we found that the origin of reintroduced wild-caught and head-started juveniles did not appear to affect the resources used during the initial establishment phase. Thus, our results suggest that conditions experienced during the first several years of life might not strongly influence habitat preferences in tuatara. We conclude that future translocations of tuatara can use either head-started or wild-caught juvenile tuatara as founders.

\section{Acknowledgements}

For providing the necessary permits, approval and consultation, we are grateful to the Department of Conservation (permit NM-32559-FAU), the University of Otago Animal Ethics Committee (AEC permit 102-11), Ngāti Koata (kaitiaki of tuatara from Stephens Island/Takapourewa), Kāti Huirapa Rūnaka ki Puketeraki (mana whenua of Otago), and the Otago Natural History Trust. We thank numerous people, including Anne Besson, Luke Easton, Nicola Nelson, Susan Keall, Sophie Penniket, Edward Ramirez, Alister Robinson, Mel Rodríguez, and Ngāti Koata representatives, who assisted with the harvest, release and/or monitoring of tuatara. We thank the journal editorial team, David Towns, Anna Carter, Anne Besson, and Sophie Penniket for comments that improved the manuscript, Alistair Senior, Shinichi Nakagawa, and Tim Jowett for statistical advice, and Kelvin Lloyd for advice on vegetation at the release site. We are grateful to Ōrokonui Ecosanctuary personnel, especially Elton Smith, Valerie Fay, and Chris Baillie, for their support.

\section{References}

AebischerNJ, Robertson P, Kenward RE 1993. Compositional analysis of habitat use from animal radio-tracking data. Ecology 74: 1313-1325.

Alldredge JR, Griswold J 2006. Design and analysis of resource selection studies for categorical resource variables. Journal of Wildlife Management 70: 337-346.

Armstrong DP, Seddon PJ 2008. Directions in reintroduction biology. Trends in Ecology \& Evolution 23: 20-25.

Bakken GS, Angilletta MJ 2013. How to avoid errors when quantifying thermal environments. Functional Ecology 28: 96-107.

Bakken GS, Gates DM 1975. Heat-transfer analysis of animals: some implications for field ecology, physiology, and evolution. In: Gates DM, Schmerl RB eds Perspectives of biophysical ecology. New York, Springer-Verlag. Pp. 255-290.

Bartoń K 2015. MuMIn: Multi-model inference. R package version 1.9.13. http://CRAN.R-project.org/ package $=$ MuMIn.

Bates D, Maechler M, Bolker B, Walker S 2015. lme4: Linear mixed-effects models using Eigen and S4. R package version 1.0-6. http://CRAN.R-project.org/package=lme4.

Besson AA, Cree A 2010. A cold-adapted reptile becomes a more effective thermoregulator in a challenging environment. Oecologia 163: 571-581.

Blouin-Demers G, Weatherhead PJ 2001a. Thermal ecology of the black rat snake (Elaphe obsoleta) in a thermally challenging environment. Ecology 82: 3025-3043.

Blouin-Demers G, Weatherhead PJ 2001b. Habitat use by black rat snakes (Elaphe obsoleta obsoleta) in fragmented forests. Ecology 82: 2882-2896.

Boyce MS, Vernier PR, Nielsen SE, Schmiegelow FKA 2002. Evaluating resource selection functions. Ecological Modelling 157: 281-300.

Burnham KP, Anderson DR 2002. Model selection and multimodel inference. New York, Springer.

Burns B, Innes J, Day T 2012. The use and potential of pest-proof fencing for ecosystem restoration and fauna conservation in New Zealand. In: Somers MJ, Hayward MW eds Fencing for conservation: restriction of evolutionary potential or a riposte to threatening processes? New York, Springer. Pp. 65-90.

Calenge $\mathrm{C} 2006$. The package adehabitat for the R software: a tool for the analysis of space and habitat use by animals. Ecological Modelling 197: 516-519.

Christian KA, Tracy CR 1981. The effect of the thermal environment on the ability of hatchling Galapagos land iguanas to avoid predation during dispersal. Oecologia 49: 218-223.

Corkery I, Bell BD, Nelson NJ 2014. Behavioral thermoregulation of the tuatara, Sphenodon punctatus, under hydric and digestive constraints. Herpetological Conservation and Biology 9: 29-37.

CreeA 1994. Low annual reproductive output in female reptiles from New Zealand. New Zealand Journal of Zoology 21: 351-372.

Cree A 2014. Tuatara: biology and conservation of a venerable survivor. Christchurch, Canterbury University Press.

Crook IG 1975. The tuatara. In: Kuschel G ed Biogeography and ecology in New Zealand. Junk, The Hague. Pp. 331-352.

Davis JM, Stamps JA 2004. The effect of natal experience 
on habitat preferences. Trends in Ecology \& Evolution 19: 411-416.

Dawbin WH 1982. The tuatara, Sphenodon punctatus: aspects of life history, growth and longevity. In: Newman DG ed New Zealand herpetology. Wellington, New Zealand Wildlife Service. Pp. 237-250.

DeGregorio BA, Weatherhead PJ, Tuberville TD, Sperry JH 2013. Time in captivity affects foraging behavior of ratsnakes: implications for translocation. Herpetological Conservation and Biology 8: 581-590.

Dormann CF, Elith J, Bacher S, Buchmann C, Carl G, Carré G, Marquéz, Gruber B, Lafourcade B, Leitão, Münkemüller T, McClean C, Osborne PE, Reineking B, Schröder B, SkidmoreAK, Zurell D, Lautenbach S 2013. Collinearity: a review of methods to deal with it and a simulation study evaluating their performance. Ecography 36: 027-046.

Downes S, Shine R 1998. Heat, safety or solitude? Using habitat selection experiments to identify a lizard's priorities. Animal Behaviour 55: 1387-1396.

Gaze P 2001. Tuatara recovery plan 2001-2011. Threatened species recovery plan no. 47. Wellington, New Zealand, Department of Conservation.

Gillies CS, Hebblewhite M, Nielsen SE, Krawchuk MA, Aldridge CL, Frair JL, Saher DJ, Stevens CE, Jerde CL 2006. Application of random effects to the study of resource selection by animals. Journal of Animal Ecology 75: 887-898.

Greene HW 1988. Antipredator mechanisms in reptiles. In: Gans C, Huey RB eds Biology of the Reptilia, vol. 16. New York, Wiley. Pp. 1-152.

Greenwald OE 1974. Thermal dependence of striking and prey capture by gopher snakes. Copeia 1974: 141-148.

Griffith B, Scott JM, Carpenter JW, Christine R 1989. Translocations as a species conservation tool: status and strategy. Science 245: 477-480.

Grueber CE, Nakagawa S, Laws RJ, Jamieson IG 2011. Multimodel inference in ecology and evolution: challenges and solutions. Journal of Evolutionary Biology 24: 699-711.

Fischer J, Lindenmayer DB 2000. An assessment of the published results of animal relocations. Biological Conservation 96: 1-11.

Hay JM, Sarre SD, Lambert DM, Allendorf FW, Daugherty CH 2010. Genetic diversity and taxonomy: a reassessment of species designation in tuatara (Sphenodon: Reptilia). Conservation Genetics 11: 1063-1081.

Hoare JM, Pledger S, Nelson NJ, Daugherty CH 2007. Avoiding aliens: behavioural plasticity in habitat use enables large, nocturnal geckos to survive Pacific rat invasions. Biological Conservation 136: 510-519.

Huey RB 1982. Temperature, physiology, and the ecology of reptiles. In: Gans C, Pough FH eds Physiology C: Physiological Ecology. London, Academic Press. Pp. 25-91.

Huey RB 1991. Physiological consequences of habitat selection. American Naturalist 137: 91-115.

Huey RB, Peterson CR, Arnold SJ, Porter WP 1989. Hot rocks and not-so-hot rocks: retreat-site selection by garter snakes and its thermal consequences. Ecology 70: 931-944.

Huey RB, Pianka ER 1981. Ecological consequences of foraging mode. Ecology 62: 991-999.

IUCN/SSC 2013. Guidelines for Reintroductions and Other Conservation Translocations. Version 1.0. Gland, Switzerland, IUCN Species Survival Commission.
Jarvie S, Besson AA, Seddon PJ, Cree A 2014a. Assessing the thermal suitability of translocation release sites for egg-laying reptiles with temperature-dependent sex determination: a case study with tuatara (Sphenodon punctatus). Animal Conservation 17: 48-55.

Jarvie S, Ramirez AE, Dolia J, Adolph SC, Seddon PJ, Cree A 2014b. Attaching radio-transmitters does not affect mass, growth or dispersal of translocated juvenile tuatara (Sphenodon punctatus). Herpetological Review 45: 417-421.

Jarvie S, Senior AM, Adolph SC, Seddon PJ, Cree A 2015. Captive-rearing affects growth but not survival in translocated juvenile tuatara. Journal of Zoology 297: 184-193.

Johnson DH 1980. The comparison of usage and availability measurements for evaluating resource preference. Ecology 61: 65-71.

Jones MEH, Cree A 2012. Tuatara. Current Biology 22: 986-987.

Kemp L, Norbury G, Groenewegen R, Comer S 2015. The roles of trials and experiments in fauna reintroduction programs. In: Armstrong DP, Hayward M, Moro D, Seddon PJ eds Advances in reintroduction biology of Australia and New Zealand fauna. Clayton, Australia, CSIRO Publishing. Pp. 73-89.

Kokko H, Sutherland WJ 2001. Ecological traps in changing environments: ecological and evolutionary consequences of a behaviourally mediated Allee effect. Evolutionary Ecology Research 3: 537-551.

Lima SL, Dill LM 1990. Behavioral decisions made under the risk of predation: a review and prospectus. Canadian Journal of Zoology 68: 619-640.

Manly BFJ, McDonald LL, Thomas DL, McDonald TL, Erickson WP 2002. Resource selection by animals: statistical design and analysis for field studies. Dordrecht, Kluwer Academic.

Martin J, Lopez P 1995. Influence of habitat structure on the escape tactics of the lizard Psammodromus algirus. Canadian Journal of Zoology 73: 129-132.

Martín J, López P 1999. When to come out from a refuge: risk-sensitive and state dependent decisions in an alpine lizard. Behavioural Ecology 10: 487-492.

Mello RSR, Besson AA, Hare KM, Fay V, Smith E, Cree A 2013. Adjustment of juvenile tuatara to a cooler, southern climate: operative temperatures, emergence behaviour and growth rate. New Zealand Journal of Zoology 142: 1-14.

Miller KA, Nelson NJ, Smith HG, Moore JA 2009. How do founder group size and reproductive skew affect genetic diversity in reintroduced populations? Molecular Ecology 18: 3792-3802.

Miller KA, Miller HC, Moore JA, Mitchell NJ, CreeA, Allendorf FW, Sarre SD, Keall SN, Nelson NJ 2012. Securing the demographic and genetic future of tuatara through assisted colonization. Conservation Biology 26: 790-798.

Moore JA, Hoare J, Daugherty CH, Nelson NJ 2007. Waiting reveals waning weight: Monitoring over 54 years shows a decline in body condition of a long-lived reptile (tuatara, Sphenodon punctatus). Biological Conservation 135: 181-188.

Moore JA, Daugherty CH, Nelson NJ 2009. Large male advantage: phenotypic and genetic correlates of territoriality in tuatara. Journal of Herpetology 43: 570-578. 
Nakagawa S, Schielzeth H 2013. A general and simple method for obtaining $\mathrm{R}^{2}$ from generalized linear mixed-effect models. Methods in Ecology \& Evolution 4: 133-142.

Nelson, N. 1998. Conservation of Brothers Island tuatara (Sphenodon guntheri). MConSc thesis. Victoria University of Wellington, Wellington. 262 p.

Nelson NJ, Keall SN, Brown D, Daugherty CH 2002. Establishing a new wild population of tuatara (Sphenodon guntheri). Conservation Biology 16: 887-894.

Newman DG 1987. Burrow use and population densities of tuatara (Sphenodon punctatus) and how they are influenced by fairy prions (Pachyptila turtur) on Stephen's Island, New Zealand. Herpetologica 43: 336-344.

Osborne PE, Seddon PJ 2012. Selecting suitable habitats for reintroductions: variation, change and the role of species distribution modelling. In: Ewen JG, Armstrong DP, Parker KA, Seddon PJ eds Reintroduction biology: integrating science and management. Oxford, Wiley-Blackwell. Pp. 73-104.

Pinheiro J, Bates D, DebRoy S, Sarkar D, R Core Team 2014. nlme: Linear and Nonlinear Mixed Effects Models. R package version 3.1-117, http://CRAN.R-project.org/ package $=$ nlme

Pritchard PCH 1979. 'Headstarting' and other conservation techniques for marine turtles. International Zoology Yearbook 19: 38-42.

Sarrazin F, Barbault R 1996. Reintroduction: challenges and lessons for basic ecology. Trends in Ecology \& Evolution 11: 474-479.

Schielzeth H2010. Simple means to improve the interpretability of regression coefficients. Methods in Ecology \& Evolution 1: 103-113.

Seddon PJ, Armstrong DP, Maloney RF 2007. Developing the science of reintroduction biology. Conservation Biology 21: $303-312$.

Seddon PJ, Griffiths CJ, Soorae PS, Armstrong DP 2014. Reversing defaunation: Restoring species in a changing world. Science 345: 406-412.

Sinervo B, Adolph SC 1989. Thermal sensitivity of growth rate in hatchling Sceloporus lizards: environmental, behavioral and genetic aspects. Oecologia 78: 411-419.

Skoczylas R 1978. Physiology of the digestive tract. In: Gans C, Gans KAeds Biology of the Reptilia. Vol. 8. Physiology

Editorial board member: Deb Wilson

Received 26 June 2015; accepted 19 December 2015

\section{Supplementary Material}

Additional supporting information may be found in the online version of this article:

Table S1. Coefficients from linear mixed-effect models (LMM) used to calculate the operative temperature at night-time for four habitats at Ōrokonui Ecosanctuary, South Island, New Zealand

Table S2. Parameter estimates and relative importance from resource selection functions for juvenile tuatara (Sphenodon punctatus) following a reintroduction to Ōrokonui Ecosanctuary, South Island, New Zealand.

Table S3. Predictors in each candidate model evaluated from resource selection functions for juvenile tuatara (Sphenodon
B. New York, Academic Press. Pp. 589-717.

Snyder NFR, Derrickson SR, Beissinger SR, Wiley JW, Smith TB, Toone WD, Miller B 1996. Limitations of captive breeding in endangered species recovery. Conservation Biology 10: 338-348.

Stamps JA, Swaisgood RR 2007. Someplace like home: experience, habitat selection and conservation biology. Applied Animal Behaviour Science 102: 392-409.

Symonds MRE, Moussalli A 2011. A brief guide to model selection, multimodal inference and model averaging in behavioural ecology using Akaike's information criterion. Behavioural Ecology \& Sociobiology 65: 13-21.

Thompson MB, Daugherty CH 1988. Metabolism of tuatara Sphenodon punctatus. Comparative Biochemistry \& Physiology 119: 519-522.

R Development Core Team 2015. R: A language and environment for statistical computing. R Foundation for Statistical Computing, Vienna. http://www.R-project.org.

Rittenhouse C, Millspaugh J, Hubbard M, Sheriff S, Dijak W 2008. Resource selection by translocated three-toed box turtles in Missouri. Journal of Wildlife Management 72: 268-275.

Roe J, Frank M, Gibson S, Attum O, Kingsbury B 2010. No place like home: an experimental comparison of reintroduction strategies using snakes. Journal of Applied Ecology 47: 1253-1261.

Venables WN, Ripley BD 2002. Modern Applied Statistics with S-PLUS. $4^{\text {th }}$ edn. New York, Springer-Verlag.

Vitt LJ, Caldwell JP 2014. Herpetology: an introductory biology of amphibian and reptiles. $4^{\text {th }}$ edn. San Diego, CA, Academic Press.

Walls GY 1983. Activity of the tuatara and its relationships to weather conditions on Stephens Island, Cook Strait, with observations on geckos and invertebrates. New Zealand Journal of Zoology 10: 309-317.

Webb JK, Whiting MJ 2005. Why don't small snakes bask? Juvenile broad-headed snakes trade thermal benefits for safety. Oikos 110: 515-522.

Wilmshurst JM, Anderson AJ, Higham TFG, Worthy TH 2008. Dating the late prehistoric dispersal of Polynesians to New Zealand using the commensal Pacific rat. Proceedings of the National Academy of Sciences USA 105: 7676-7680.

Wolf CM, Griffith B, Reed C, Temple SA 1996. Avian and mammalian translocations: update and reanalysis of 1987 survey data. Conservation Biology 10: 1142-1154.

punctatus) from three groups following a reintroduction to Ōrokonui Ecosanctuary, South Island, New Zealand.

Table S4. Candidate models for resource selection functions for juvenile tuatara (Sphenodon punctatus) from three groups following a reintroduction to Ōrokonui Ecosanctuary, South Island, New Zealand.

The New Zealand Journal of Ecology provides online supporting information supplied by the authors where this may assist readers. Such materials are peer-reviewed and copyedited but any issues relating to this information (other than missing files) should be addressed to the authors. 